\title{
Prikaz i razvoj Cochrane sustavnog preglednog rada intervencija
}

\section{Presentation and development of Cochrane systematic review of interventions}

\author{
Tin Nadarević ${ }^{1 *}$, Vanja Giljača², Damir Miletić ${ }^{1}$, Davor Štimac ${ }^{2}$
}

\begin{abstract}
Sažetak. Sustavni pregledni radovi danas se smatraju dijelom relevantne znanstvene i stručne literature koja postaje neizostavni dio svakodnevne medicinske prakse i važan element $u$ donošenju odluka. Radi se o znanstvenom istraživanju koje temeljem sustavne i strogo definirane metodologije pretrage, odabira i analize dostupnih znanstvenih dokaza daje odgovor na točno definirano znanstveno pitanje. Cochrane kolaboracija je svjetska neprofitna organizacija čiji je cilj stvaranje kvalitetnih sustavnih preglednih radova kroz detaljnu, razrađenu i rigoroznu metodologiju. Kroz različite znanstvene grupe autori publiciraju Cochrane sustavne preglede intervencija i dijagnostičkih testova koji se objavljuju u bazi sustavnih preglednih članaka Cochrane. Cochrane sustavni pregledni rad razvija se u nekoliko koraka: formulacija pitanja, odabir Cochrane skupine, registracija naslova, izrada i objava protokola te izrada, objava i održavanje sustavnog preglednog rada. Ovim radom želimo prikazati metodologiju razvoja sustavnog pregleda u sklopu Cochrane kolaboracije kao općenit uvid u kompleksnost njegove izrade.
\end{abstract}

Ključne riječi: Cochrane kolaboracija; knjižnica Cochrane; medicina bazirana na dokazima; sustavni pregledni članci

\begin{abstract}
Systematic review articles are considered as a part of relevant scientific and professional literature which has become an infallible part of everyday medical practice and a vital part in decision making. This scientific work is based on the systematic and strictly defined methodology of research, selection and analysis of available medical evidence which provides and answer to a specific scientific question. The Cochrane Collaboration is a world non-profit organizaton whose goal is to publish high qualitiy systematic reviews through detailed and rigorous methodology. Through out different scientific groups, authors publish Cochrane systematic reviews of interventions and diagnostic tests which are published in the Cochrane Database of Systematic Reviews. These reviews develope in several steps: question formulation, Cochrane group selection, title registration, writing and publishing a protocol and writing, publishing and updating a systematic review. In this article we wish to present the methodology of Cochrane systematic review development as a general insight into its complexity.
\end{abstract}

Key words: Cochrane collaboration; Cochrane library; evidence based medicine; systematic review articles
${ }^{1}$ Klinički zavod za radiologiju, Klinički bolnički centar Rijeka, Rijeka

'Zavod za gastroenterologiju, Klinika za internu medicinu, Klinički bolnički centar Rijeka, Rijeka

*Dopisni autor:

Tin Nadarević, dr. med.

Klinički zavod za radiologiju, KBC Rijeka Krešimirova 42, 51000 Rijeka

e-mail: tin.nadarevic@gmail.com

http://hrcak.srce.hr/medicina 


\section{UVOD}

Svakodnevni rad liječnika ispunjen je donošenjem važnih odluka kojima se pacijentima postavlja dijagnoza te ordinira adekvatna terapija, intervencija ili zahvat. Odluka se donosi na temelju kliničkog iskustva i znanja. Kliničko iskustvo dobiva se svakim satom boravka s pacijentom $u$ bolničkom i izvanbolničkom sustavu, a znanje temeljem činjenica i informacija koje su u današnje vrijeme dostupne pritiskom tipke na mišu kom-

Sustavni pregledni radovi danas se smatraju dijelom relevantne znanstvene i stručne literature koja postaje neizostavni dio svakodnevne medicinske prakse i važan element u donošenju odluka.

pjutora. Danas, kada eksponencijalno raste broj dostupnih kliničkih studija, informacija i iskustava, postavlja se pitanje koje su to referentne kliničke informacije koje liječnik može implementirati u svakodnevnu praksu. Gdje se može naći odgovor na pitanje hoće li liječnik primijeniti lijek A ili B za liječenje pacijenta, hoće li se primijeniti konzervativni ili kirurški način liječenja, hoće li intervencija A ili B biti bolja za pacijenta? Odgovor se nalazi u dokazima - znanstveno utemeljenim činjenicama koje proizlaze iz metodološki zahtjevnih znanstvenih istraživanja. Unazad nekoliko desetljeća sve je teže pratiti novija zbivanja, postignuća i rezultate u određenoj grani medicine te se javila potreba za sustavnim pregledom literature i znanstvenom analizom rezultata, s ciljem da se tako provodi u djelo medicina temeljena na dokazima.

\section{SUSTAVNI PREGLEDNI RAD}

Sustavni pregledni rad je znanstveni rad koji temeljem sustavne i strogo definirane metodologije pretrage, odabira i analize dostupnih znanstvenih dokaza daje odgovor na točno definirano znanstveno pitanje. Radi se o posebnom obliku istraživanja aktualne dostupne literature $u$ kojem se sustavnom pretragom relevantnih medicinskih baza, pažljivim odabirom znanstvenih radova i statističkom analizom njihovih rezultata dolazi do zaključaka koji predstavljaju objektivan dokaz primjenjiv u svakodnevnoj praksi. Sustavni pregledni rad daje konačnu informaciju temeljenu na dokazima čija primjena u kliničkoj praksi ima adekvatnu težinu.

Ova se vrsta znanstvenog istraživanja razlikuje od opisnog preglednog rada u kojem se obično na temelju literature dostupne autoru donose informacije obogaćene iskustvom stručnjaka koji izrađuje taj rad. U takvim radovima obično se daje širok sažetak trenutnih zbivanja u određenom znanstvenom području, no oni su vrlo često podložni znanstvenoj pogrešci (engl. selection bias) i često se ne navodi metodologija kojom se pretraživalo, određivalo i analiziralo autoru dostupne dokaze. Opisni pregledni radovi ne uključuju sustavni pregled literature, fokusiraju se na literaturu određenog područja koju je autor uspio pronaći i navode statističku značajnost u radovima koji su prethodno provedeni. Sustavni pregledni radovi sadrže prethodno definiranu strategiju s ciljem smanjivanja pristranosti ili pogreške, statističku analizu (metaanalizu) i veličinu učinka ${ }^{1}$.

Uzmimo za primjer endoskopsku sfinkterotomiju (EST) i endoskopsku balonsku dilataciju (EBD) u liječenju koledokolitijaze. Pregledni rad podrazumijeva potragu za dostupnom literaturom koja opisuje uspjeh ovih metoda u smislu uspješne ekstrakcije koledokolita i broja postproceduralnih komplikacija te se navodi koja je studija proizvela kakve rezultate, iz čega se donosi zaključak. U sustavnom preglednom radu uzimaju se relevantne kliničke studije odabrane sustavnom pretragom literature i metodološki adekvatnom analizom radova donosi se zaključak oko toga koja je metoda bolja u liječenju koledokolitijaze.

Već dugo vremena postoji problem sažimanja literature o određenoj medicinskoj tematici zbog velike količine informacija, no tek potkraj 20. stoljeća sustavno sažimanje znanstvenih dokaza dobilo je svoj formalni oblik². Prvi sustavni pregledni rad objavio je Chalmers 1979. godine o fetalnom monitoringu ${ }^{3}$. Britanski epidemiolog Archibald (Archie) Cochrane temeljem svog istraživanja naveo je da je velika kritika naše profesije u tome što nismo uspjeli organizirati kritički sažetak svih randomiziranih kliničkih studija, što je potaknulo laina Chalmersa, britanskog liječnika i istraživača, na osnivanje organizacije s ciljem stvaranja znan- 
stveno utemeljenog sažimanja dostupne literature i dokaza u medicini ${ }^{4}$.

\section{Cochrane kolaboracija}

Cochrane kolaboracija je svjetska neprofitna organizacija čiji je cilj pripremanje, održavanje i promicanje dostupnosti sustavnih preglednih članaka o učincima zdravstvenih intervencija ${ }^{5}$. Osnovana je 1993. godine i danas se sastoji od oko 37.000 volontera iz 130 zemalja svijeta, čiji je cilj omogućiti dostupnima znanstvene informacije koje su neovisne o sponzorskim istraživanjima i sukobu interesa6 ${ }^{6}$. Cochrane kolaboracija danas predstavlja najveću organizaciju koja se bavi sustavnim preglednim radovima i međunarodno je priznata i respektabilna inicijativa. Zadatak kolaboracije je da potiče autore na izradu sustavnih preglednih radova, sprječava duplikaciju radova $\mathrm{i}$ daje pomoć autorima. Članovi kolaboracije organizirani su u različite skupine: Cochrane skupine za pregledne članke, Cochrane centri, Cochrane skupine za metode, Cochrane mreže i Cochrane mreže pacijenata. Rad se odvija kroz 53 različite grupe Cochrane koje su odgovorne za sustavne preglede u svom specifičnom području zdravstvene skrbi ${ }^{7}$. Cochrane centri su regionalni centri koji fokusiraju svoju aktivnost na određeno zemljopisno područje u smislu edukacije i poticanja izrade sustavnih preglednih radova, kao i odnos s regionalnim zdravstvenim sustavima. Cochrane mreže bave se drugim dimenzijama zdravstvene skrbi, kao što je smještaj u kojem se pruža njega, tip intervencije ili tip korisnika, a mreže pacijenata pružaju informacije korisnicima i koriste forum za njihovo umrežavanje ${ }^{8}$.

\section{Knjižnica Cochrane}

Knjižnica Cochrane glavni je proizvod Cochrane kolaboracije i predstavlja skup baza podataka koji sadrže visokokvalitetne dokaze u medicini. Sustavni pregledi Cochrane predstavljaju najveću razinu dokaza u donošenju odluka u dijagnostici i liječenju pacijenata ${ }^{5,9}$. Knjižnica se sastoji od sljedećih baza: baza sustavnih preglednih članaka Cochrane (engl. Cochrane Database of Systematic Reviews), baza sažetaka preglednih članaka o učincima (engl. Database of Abstracts of Review fo Effects), registar Cochrane metodologije (engl. Cochrane Mehodology Register), središnji regi- star kontroliranih pokusa Cochrane (engl. Cochrane Central Register of Controlled Trials - CENTRAL), baza procjene zdravstvene tehnologije (engl. Health Technology Assessment Database) i baza ekonomskih evaluacija Nacionalne zdravstvene službe (engl. National Health Service Evonomic Evaluation Database). Izdanje 03/2017 knjižnice Cochrane sadrži ukupno 7.258 preglednih radova i 2.543 protokola ${ }^{10}$. Impact factor (IF) baze sustavnih preglednih članaka Cochrane za 2015. godinu bio je 6,103 . Cochrane sustavni pre-

Cochrane sustavni pregledni radovi zahtijevaju temeljitu i objektivnu pretraživačku strategiju, što je jedna od glavnih razlika u odnosu na opisne pregledne radove.

gledi postaju sve popularniji i važniji ne samo za zdravstvene djelatnike već i za rukovoditelje zdravstvenih institucija i sustava, što se vidi u porastu broja studija koje se objavljuju u bazi sustavnih preglednih članaka Cochrane ${ }^{11}$.

\section{RAZVOJ SUSTAVNOG PREGLEDNOG RADA}

Sustavni pregledni rad Cochrane razvija se u nekoliko koraka: formulacija pitanja, odabir Cochrane skupine, registracija naslova, izrada i objava protokola te izrada, objava i održavanje sustavnog preglednog rada (slika 1). Cochrane kolaboracija objavila je okvirna vremenska razdoblja

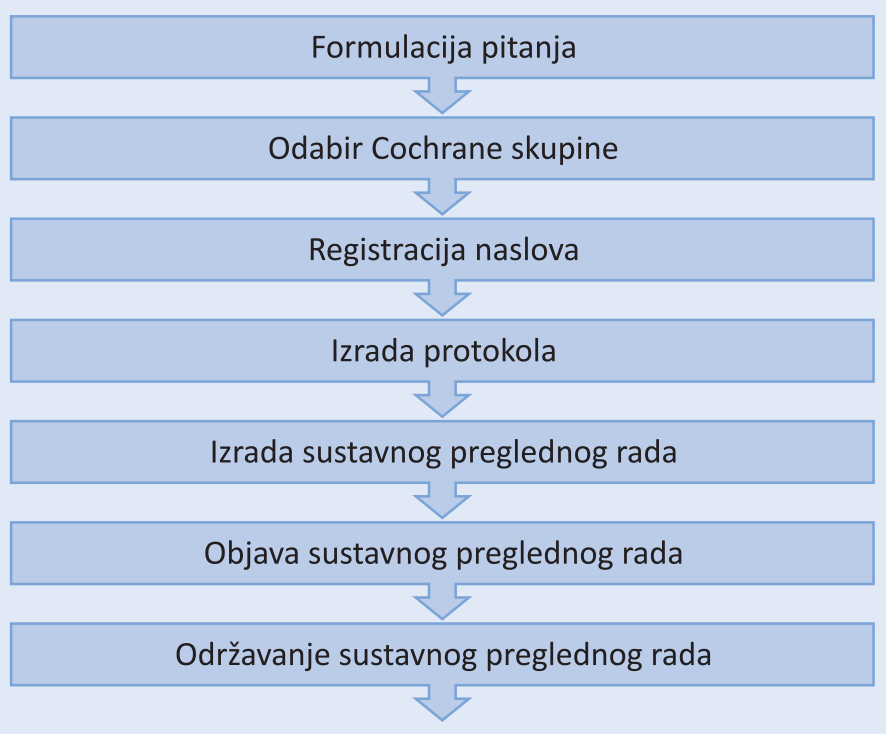

Slika 1. Koraci u izradi sustavnog preglednog rada 
potrebna za izvršenje pojedinog koraka radi adekvatnog planiranja rada (tablica 1$)^{12}$.

\section{Formulacija pitanja}

Prvi korak u izradi Cochrane sustavnog preglednog rada je postavljanje znanstvenog pitanja. Točno definirani i ciljani rad započinje dobro oblikovanim pitanjem. Kao pomoć u izradi pitanja koristi se engleski akronim PICOS (engl. Participants, Interventions, Compare, Outcomes, Study). Potrebno je odrediti sudionike (engl. participants), tj. ciljanu populaciju studije. Zatim je potrebno definirati intervenciju (engl. intervention) koju želimo ispitivati, poput lijeka, uređaja ili usluge. Potom se određuje standard s kojim se uspoređuje (engl. compare) odabrana intervencija. Važno je odlučiti koje se ishode (engl. outcomes) želi pratiti te utvrditi prednosti i mane odabrane intervencije. I konačno, određuje se vrsta studija (engl. study) koje će biti adekvatna za uključivanje u analizu. $U$ većini slučajeva radi se o randomiziranim kliničkim studijama.

\section{Odabir Cochrane skupine}

Cochrane skupine predstavljaju skupine osoba koji se bave određenim područjem u zdravstvu (hepato-bilijarni sustav, srce, karcinom dojke, dišni sustav, hipertenzija itd.). Ako se odabrano znanstveno pitanje može obrađivati u dvije ili više različitih grupa, autor kontaktira s jednom od skupina te se odlučuje među skupinama od interesa koja će biti nositelj prijavljene teme. Cochrane skupina sastoji se od dvaju urednika od kojih je jedan vodeći (engl. Managing Editor), čija je zadaća dnevni menadžment u sjedištu određene grupe, a drugi (engl. Co-ordinating Editor) je član uredničkog odbora čija je prva zadaća održavanje produktivnosti i učinkovitosti grupe kao i osnovnih principa kolaboracije Cochrane. Koordinator pretrage studija (engl. Trials Search Co-ordinator) zadužen je za pretragu studija u smislu predlaganja i razvoja metodologije pretrage ili čak samo izvođenje pretrage. Cochrane skupina sastoji se i od uredničkog odbora koji može brojiti i do 20-ak stručnjaka čija je zadaća recenzija protokola i izrađenih sustavnih preglednih radova, kao i podnošenje kritika na rad autora. Ostali članovi grupe su: statističari, vanjski recenzenti, pretraživači tiskane literature, korisnici i sami autori.

\section{Registracija naslova}

Nakon odabira određene Cochrane skupine potrebno je proučiti njihovu web-stranicu i provjeriti postoji li već registriran naslov i tema koja se želi obraditi. Ako naslov ne postoji, on se prijavljuje na posebnom obrascu s kratkim opisom istraživanja. Mnoge Cochrane skupine imaju unaprijed određene prioritete o temama koje bi se trebale obrađivati. Unutar skupine se potom vodi diskusija o predloženom naslovu, kao i njegovo kruženje među drugim skupinama, kako bi se isključila preklapanja tema u knjižnici Cochrane. Ako prijavljena tema nije do sada obrađivana, naslov će se registrirati i grupa će pozvati autore naslova na izradu protokola studije.

Tablica 1. Okvirni vremenski periodi potrebni za izradu pojedinog zadatka

\begin{tabular}{|c|l|}
\hline Mjeseci & \multicolumn{1}{|c|}{ Aktivnost } \\
\hline $1-2$ & Priprema protokola \\
\hline $3-8$ & Pretraga objavljenih i neobjavljenih studija \\
\hline $2-3$ & Testiranje uključnih kriterija \\
\hline $3-8$ & Procjena uključnih kriterija \\
\hline 3 & Testiranje procjene rizika od sustavne pogreške. \\
\hline $3-10$ & Procjene valjanosti \\
\hline 3 & Testiranje prikupljanja podataka \\
\hline $3-10$ & Prikupljanje podataka \\
\hline $3-10$ & Unos podataka \\
\hline $5-11$ & Praćenje nedostupnih podataka \\
\hline $8-10$ & Analiza \\
\hline $1-11$ & Priprema rada \\
\hline $12-$ & Ažuriranje rada \\
\hline
\end{tabular}




\section{Izrada protokola}

Cochrane protokol predstavlja plan izrade sustavnog preglednog rada. Smatra se predloškom izrade preglednog rada i njegovih sljedećih održavanja s ciljem smanjivanja sustavne pogreške i osiguravanja transparentnosti. Protokolom se opisuje medicinska problematika (bolest ili stanje), intervencija ili dijagnostički test, ciljevi rada, uključni i isključni kriteriji, metode pretrage literature, analize podataka, procjene kvalitete studija te statistička analiza podataka. Jednostavno rečeno, protokol detaljno opisuje metodologiju koja će se koristiti pri izradi sustavnog preglednog rada. Cochrane protokoli, a kasnije i sustavni pregledni rad, izrađuju se u kompjutorskom programu Review Manager 5 (RevMan5) i imaju unaprijed strogo definirani format zbog jasnog i preciznog priopćavanja rezultata, brzog nalaženja bitnih informacija i jednostavnog elektroničkog objavljivanja. Izrada takvog rada je kompleksna i podložna je brojnim analizama i kritikama. Kako bi se smanjila sustavna pogreška, te kritike trebale bi biti usmjerene na samu metodologiju bez utjecaja na rezultat studije. Unaprijed poznati rezultati studije mogu utjecati na definiciju znanstvenog pitanja, uključne i isključne kriterije te odabir referentnog standarda. Stoga objava protokola sustavnog preglednog rada prije znanja o dostupnim studijama smanjuje mogućnost sustavne pogreške od strane autora, promiče transparentnost metodologije, smanjuje mogućnost duplikacije i omogućuje recenziju planiranih metoda $^{13}$. lako bi se izrada studije trebala strogo pridržavati protokola, ponekad su promjene protokola nužne. Promjenu protokola možemo usporediti s onom u randomiziranih kliničkih ispitivanja gdje je promjena nužna zbog problema s prikupljanjem sudionika i podataka ili neočekivanim događajima. $U$ tom slučaju promjena je opravdana, no nikako ne smije utjecati na ishod same studije ${ }^{12}$. Nakon prihvaćanja protokola, on se objavljuje u knjižnici Cochrane (engl. Cochrane Database of Systematic Reviews).

\section{Izrada sustavnog preglednog rada}

Metodologija izrade sustavnog preglednog rada slijedi prethodno objavljen protokol. Pristupa se pretraživanju i odabiru studija, procjenjuje se rizik sustavne pogreške uključenih studija, prikupljaju se podaci, analiziraju i interpretiraju rezultati te donose zaključci koji se moraju pisati razumljivim jezikom.

\section{Pretraživanje i odabir studija}

Cochrane sustavni pregledni radovi zahtijevaju temeljitu i objektivnu pretraživačku strategiju, što je jedna od glavnih razlika u odnosu na opisne pregledne radove. Pretraživačka strategija podrazumijeva strukturalno i logički koncipiran način

Metaanaliza je statistička metoda koja daje kvantitativni odgovor o tome koliko je određena intervencija učinkovita i koliki je stupanj sigurnosti u dobivene rezultate.

pretraživanja baza podataka temeljen na riječima i konceptima iz naslova i uključnih kriterija. Cilj sustavne pretrage je pronaći ravnotežu između široke i detaljne pretrage studija $i$ što preciznije pretrage kako bi se smanjio broj studija nebitnih za izradu sustavnog pregleda. Najvažniju ulogu u pretraživanju literature ima koordinator pretrage studija određene Cochrane grupe koji su posebno educirani i osposobljeni za sustavnu pretragu zdravstvene literature. Koordinatori nam mogu pomoći u pronalasku studija, razvoju i provođenju strategije pretraživanja, preporučiti kako da pretražujemo druge baze podataka, kako da inkorporiramo pronađenu skupinu studija u posebne softvere za uređivanje i vođenje referenci (npr. EndNote ili ProCite), te kako dokumentirati pretragu u samom preglednom radu. Osnovne baze podataka koje se moraju sustavno pretražiti su CENTRAL (Cochrane Central Register of Controlled Trials), EMBASE i MEDLINE. Postoje posebni registri studija koji su dijelom obuhvaćeni bazom podataka CENTRAL, no preporučuje se da se svi registri pretraže posebno. Registri završenih i aktualnih kliničkih studija, poput Current Controlled Trials i ClinicalTrials.gov, također su važan izvor informacija. Cjelokupne strategije pretraživanja baza podataka moraju biti navedene u dodacima sustavnog preglednog rada, a ukupni broj pronađenih studija mora se navesti u rezultatima. Nakon što se protokol studije prihvati i objavi u knjižnici Cochrane, autori obavezno moraju kontaktirati s koordinato- 
rom pretrage studija prije samostalnog izvođenja pretrage baza podataka zbog dogovora o daljnjim postupanjima. Nakon prikupljanja studija od interesa, pristupa se selekciji studija tako da se prvo isključuju studije na temelju naslova koje evidentno ne zadovoljavaju uključne kriterije. Nakon toga se pristupa drugoj selekciji studija na temelju sažetaka, gdje također isključujemo studije koje ne zadovoljavaju uključne kriterije. Sve one studije koje zadovoljavaju uključne kriterije ili nismo sigurni ako in je pravilno uključiti, ostavljaju se za detaljni-

Brojne agencije za financiranje znanosti i biomedicine, kao i stvaratelji zdravstvenih politika, sve više zahtijevaju sustavne pregledne članke kako bi pravilno usmjerili svoje djelovanje i financiranje.

ju analizu. Ovaj postupak obavezno moraju provoditi dva autora nezavisno jedan od drugoga, koji naknadno razmjenjuju mišljenja oko studija oko kojih se ne slažu. Ako se dogovor ne može postići, treći autor, obično onaj s više iskustva u izradi takvih studija, donosi odluku. Kao rezultat ove selekcije proizlazi skup studija iz kojih je potrebno prikupiti podatke.

\section{Prikupljanje podataka}

Proces prikupljanja podataka također provode dva autora nezavisno jedan od drugoga uz pomoć posebno dizajniranog obrasca. Postoje četiri kategorije informacija koje se moraju prikupiti iz studija uključenih u pregledni rad: informacije o tome zadovoljava li određena studija uključne kriterije da bi je autori prihvatili u pregledni rad, opisne informacije o studiji, informacije o kvaliteti studije te informacije o rezultatima studija $u$ posebnom formularu za podatke ${ }^{14}$. Obrazac za prikupljanje podataka je svojevrsni most između onoga što je objavljeno u uključenoj studiji i onoga o čemu će se izvijestiti u sustavnom preglednom radu. Obrazac je važan jer konkretno odražava problematiku preglednog članka koji se izrađuje i omogućuje da se izvuku relevantni podaci. Važan je jer se njime dokumentira povijest procesa prikupljanja informacija, bilježe se informacije koje su nam potrebne za izradu rada bez nepotrebnih informacija. Na taj način unos podatka u RevMan postaje jednostavan. I na kraju, obrazac je važan jer se pomoću njega uspoređuju rezultati rada među autorima i tako povećava pouzdanost prikupljenih podataka smanjujući mogućnost razvoja sustavne pogreške ${ }^{15}$.

Ako nedostaju određeni podaci važni za sustavni pregled ili nisu jasno navedeni, pristupa se kontaktiranju s autorom samih studija ili kompacije u medicinskoj industriji koja je tu studiju financirala.

\section{Procjena rizika sustavne pogreške}

Sustavna pogreška (engl. bias) je sustavna devijacija od istine koja nije nastala samo temeljem slučajnosti. Ovaj tip pogreške označava da će svaka ponavljanja metodologije određene znanstvene studije dovoditi do pogrešnih rezultata čiji će prosjek biti netočan. S druge strane, razlikujemo nasumičnu pogrešku (engl. random error) koja predstavlja nepreciznost u izvršenju zadatka ili mjerenja ${ }^{16}$. U slučaju ove pogreške, ponavljanja metodologije nekog znanstvenog istraživanja uvijek će dovesti do različitih rezultata čiji će prosjek biti točan ${ }^{17}$. Budući da u istraživanju ne možemo odrediti točan opseg sustavne pogreške, na temelju podataka dostupnih iz znanstvenog istraživanja procjenjujemo postoji li rizik od sustavne pogreške (engl. risk of bias). Rizik procjenjujemo tako da analiziramo potencijalne izvore sustavne pogreške koji se mogu naći od trenutka selekcije pacijenata do publikacije rada. Tako razlikujemo nekoliko vrsta sustavnih pogrešaka: pogreška selekcije (engl. selection bias) koja se događa pri odabiru i raspodjeli kandidata $u$ intervencijsku ili kontrolnu skupinu, pogreška izvođenja (engl. performace bias) koja se događa prilikom izlaganja kandidata intervenciji ili kontroli, pogreška osipanja (engl. attrition bias) kada se kandidati prate kroz određeno razdoblje, pogreška detekcije (engl. detection bias) kada se mjere ishodi studije i pogreška izvještaja (engl. reporting bias) koja se događa pri pisanju rada. Temeljem posebnog alata u programu RevMan (engl. Risk of Bias tool) izvodi se procjena rizika sustavne pogreške ${ }^{17}$.

\section{Analiza rezultata}

Metaanaliza je statistička metoda kojom se sintetiziraju i zajednički interpretiraju rezultati istraživanja uključenih u sustavni pregledni $\operatorname{rad}^{18}$. Termini sustavni pregledni rad i metaanaliza nisu sinonimi i često se krivo koriste. Dok metaanaliza 


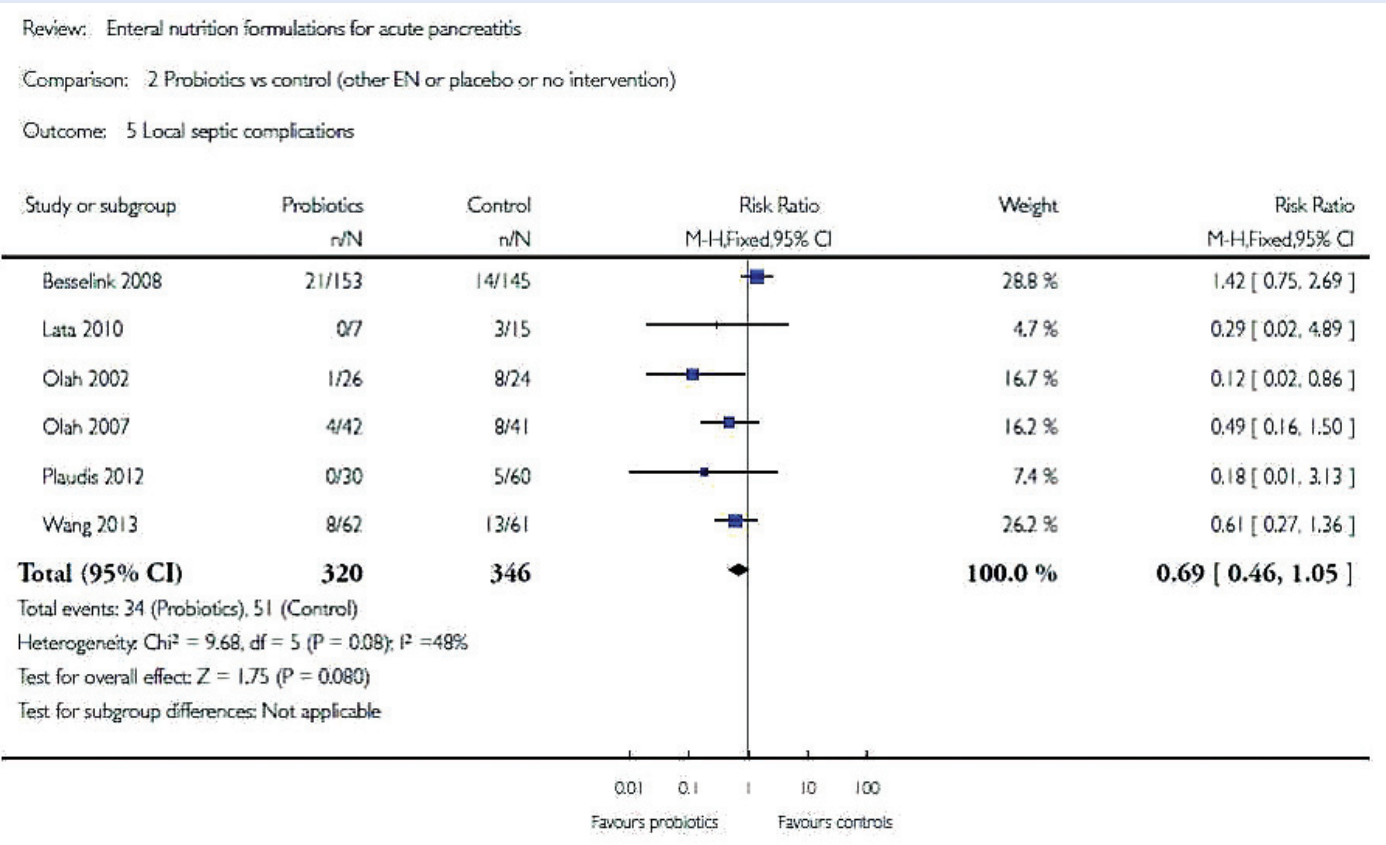

Slika 2. Metaanaliza i forest graf

označava statističku metodu, sustavni pregledni rad je znanstvena publikacija koja uključuje više relevantnih znanstvenih studija da bi se odgovorilo na konkretno postavljeno znanstveno pitanje. Sustavni pregled ne mora uvijek uključivati metaanalizu, ovisno o karakteristikama studija koje su uključene. Metaanaliza nam daje kvantitativni odgovor o tome koliko je određena intervencija učinkovita i koliki je stupanj sigurnosti u dobivene rezultate. Kombinacijom rezultata studija raste snaga detekcije razlika kao i preciznost odgovora na znanstveno pitanje. Mogu se detektirati razlike između individualnih studija i dobivamo više informacija o načinu na koji intervencija djeluje u različitim varijacijama, populacijama ili kontekstu (npr. bolničko ili izvanbolničko okruženje). Izradom metaanalize mogu se identificirati nove ideje ili hipoteze koje se mogu testirati u daljnjem radu. Ako nam individualne studije daju suprotne odgovore, metaanaliza može razriješiti kontroverzu i dati jasan odgovor. Metaanalizu je ispravno koristiti kada svaka individualna studija razmatra isto pitanje, kada se ishodi u različitim studijama mjere na isti način i kada su podaci svake studije dostupni. Metaanalizu nije prikladno provoditi kada studije imaju visoki rizik od sustavne pogreške i kada za analizu imamo samo jednu studiju. Rezultati metaanalize se grafički prikazuju pomoću forest grafova.
Izuzetno su važni u jasnom prikazu i razumijevanju podataka, prikazu heterogenosti između studija i sintetiziranog rezultata metaanalize ${ }^{19}$. Uzmimo za primjer metaanalizu iz rada Poropata i suradnika (slika 2) ${ }^{20}$. Radi se o metaanalizi koja procjenjuje učinak probiotika u razvoju lokalnih septičkih komplikacija u akutnom pankreatitisu. Analiza sadrži 6 studija od kojih svaka sadrži interventnu skupinu (probiotici) i kontrolnu skupinu (placebo, druga enteralna prehrana ili bez intervencije). U drugom i trećem stupcu navedeni su pacijenti koji su razvili septičku komplikaciju u odnosu na cijelu skupinu. U sredini je forest graf s grafičkim prikazom efekta intervencije u svakoj studiji posebno i $95 \%$ intervala pouzdanosti. Crni dijamant na dnu označava skupni efekt. Četvrti stupac označava težinu studije (ovisi o veličini uzroka), dok posljednji stupac pokazuje relativni rizik i $95 \%$-tni interval pouzdanosti. Vertikalna linija na horizontalnoj vrijednosti 1 označava liniju bez efekta (engl. line of no effect). Iz ove analize zaključuje se da probiotici nisu statistički značajno smanjili pojavnost lokalnih septičkih komplikacija ( $p=0,080)$.

\section{Heterogenost}

Heterogenost označava razliku između studija koje su uključene u sustavni pregledni rad ili metaanalizu. Kako bi se napravila skupna analiza po- 
dataka uključene studije moraju imati sličnu populaciju i koristiti slične intervencije. Te studije moraju imati i slične usporedbe kao i mjerenje istih ishoda. Heterogenost je izuzetno važan dio pri izradi sustavnog preglednog rada o kojem treba razmišljati kroz sve faze njegove izrade. Važno je znati sadržaj uključenih studija kako bismo mogli procijeniti jesu li one dovoljno slične da bi se mogle uspoređivati. Heterogenost proizlazi iz dvaju izvora: kliničkog i metodološkog. Klinička heterogenost javlja se kada postoje razlike između ispitanika, intervencija ili ishoda, a metodološka kada postoje razlike u načinu kako su studije provedene. Primjer kliničke heterogenosti studija je različita dob ispitanika: npr. jedna studija uključuje ispitanike starije od 40 godina, dok druga uključuje one mlađe. Primjer metodološke heterogenosti je u različitim načinima randomizacije ili razlikama u zasljepljivanju (engl. blinding). Nakon što smo odredili da je određena skupina studija prikladna za metaanalizu, potrebno je provjeriti daje li kombinirani učinak liječenja svih studija zajedno prikladni opis cijele grupe studija. Drugim riječima, analiziramo ako postoji statistička heterogenosti između studija. To se može učiniti na dva načina: vizualno i statistički. Vizualno se prouči forest graf i traže se preklapanja u intervalima pouzdanosti. Ako ne postoji preklapanje, postoji statistička heterogenost. Drugi način je statistički: ako je $\chi^{2}$ test veći od stupnja slobode (ukupni broj uključenih studija minus 1 ), radi se o heterogenosti. Ako je $p$ vrijednost mala (npr. $p<$ $0,05)$, navedeno upućuje na heterogenost. Postoji $I^{2}$ test koji softver RevMan automatski generira, a koji je dobar pokazatelj heterogenosti i njegova vrijednost se izražava u postocima (0 - $100 \%)$. Što je veći postotak $I^{2}$ testa, to je veći stupanj heterogenosti. Ako se detektira heterogenost, postoji nekoliko mogućih postupaka.

Prva mogućnost je ne učiniti metaanalizu jer može dovesti do netočnih rezultata i time neadekvatnih zaključaka. Ako je prisutna heterogenost, rad se može prikazati kao pregledni članak koji koristi kvalitativni pristup ili učiniti analizu samo za neke usporedbe ili ishode. Treća mogućnost je učiniti analizu podskupina pacijenata za koje postoji mogućnost različitog učinka intervencije.

Postoje dvije metode metaanalize: model fiksnog učinka (engl. fixed-effect model) i model slučajnih učinaka (engl. random effects model). Model fiksnog učinka podrazumijeva da je pojedinačni učinak svake studije isti. Prema ovoj pretpostavki svaka studija bila bi neograničeno velika i svaka bi dala identične rezultate. To je isto kao da pretpostavimo da ne postoji statistička heterogenost između studija. Model slučajnih učinaka podrazumijeva da svaka studija ima svoj učinak i da oni tvore normalnu distribuciju oko stvarnog učinka. Preporučuje se da se u metaanalizi koriste oba modela. U tom slučaju postoje tri mogućnosti: analize su iste, rezultati su slični ili različiti. Ako obje metaanalize daju iste rezultate, nije vjerojatno da postoji statistička razlika i nije bitno koju analizu prezentiramo. Ako rezultati variraju, sami moramo na temelju metodologije i zaključaka odabrati koju ćemo metodu prezentirati ${ }^{19}$. Odabir tipa metaanalize može biti zahtjevan, pa se preporučuje konzultirati sa statističarom Cochrane grupe u sklopu koje se rad izrađuje.

\section{Objava sustavnog preglednog rada}

Završetkom pisanja rad se prijavljuje odabranoj Cochrane grupi na recenziju, i to uredničkom odboru i vanjskim recenzentima. S obzirom na rigoroznu metodologiju i činjenicu da rad koji će se objaviti u knjižnici Cochrane mora zadovoljiti određene standarde, za očekivati je višestruke sugestije u vezi analize i interpretacije rezultata. Nakon prikladnih recenzija rad se objavljuje u knjižnici Cochrane (engl. Cochrane Database of Systematic Reviews).

\section{Održavanje preglednog članka}

Sustavni pregledni radovi Cochrane posebni su po tome što se redovito obnavljaju (ažuriraju), budući da je cilj Cochrane kolaboracije pružati ne samo kvalitetne dokaze u medicini i zdravstvu, već i njihova ažurnost. Trenutna je preporuka Cochrane kolaboracije da se radovi obnavljaju svake dvije godine ${ }^{21}$. Brojne agencije za financiranje znanosti i biomedicine, kao i stvaratelji zdravstvenih politika, sve više zahtijevaju sustavne pregledne članke kako bi pravilno usmjerili svoje djelovanje i financiranje. Osim navedenog, kvalitetni i ažurni dokazi izuzetno su važni u svakodnevnoj kliničkoj praksi. Ažuriranje sustavnih pregleda detekcijom i uključivanjem novih kliničkih studija može utjecati na promjenu u zaključcima tog rada, pa tako i novim dokazima. 


\section{ZAKLJUČAK}

Unazad nekoliko desetljeća jedan od glavnih problema u medicini bila je nedostupnost relevantne literature i važnih informacija koje bi nam pomogle u donošenju pravih odluka u dijagnostici i liječenju pacijenata. Danas su te informacije dostupne svima, no problem predstavlja količina podataka koju liječnik nema vremena adekvatno analizirati i donijeti znanstveno utemeljenu medicinsku odluku. Cochrane sustavnim preglednim radovima uspješno se pretražuju, sistematiziraju i analiziraju medicinske informacije na temelju kojih se donosi relevantan zaključak donesen na utemeljenim znanstvenim činjenicama. Zahvaljujući Cochrane kolaboraciji i njihovim sustavnim preglednim radovima današnji liječnik sa sigurnošću se može osloniti na relevantni znanstveni dokaz o tome koji je lijek, intervencija ili pristup potreban pacijentu i koje će terapijske protokole slijediti u njegovom liječenju. Cochrane studije važne su i u zdravstvenoj politici za izradu smjernica i protokola postupanja kod pojedinih bolesti ili stanja, standarda i normativa, nacionalnih preventivnih programa te planova racionalizacije zdravstvenih sustava. Konačno, praktičnom upotrebom rezultata Cochrane sustavnih preglednih radova prakticiramo medicinu baziranu na dokazima.

Izjava o sukobu interesa: autori izjavljuju da ne postoji sukob interesa.

\section{LITERATURA}

1. Mulrow CD. Rationale for systematic reviews. BMJ 1994;309:597-9.

2. Chalmers I, Hedges LV, Cooper H. A brief history of research synthesis. Eval Health Prof 2002;25:2-37.

3. Chalmers I. Randomized controlled trials of fetal monitoring 1973-1977. In: Thalhammer O, Baumgarten K, Pollak A (eds). Perinatal Medicine. Stuttgart: Georg Thieme,1979;260-5.

4. Cochrane AL. 1931-1971: A critical review with particular reference to the medical profession. In: Teeling-Smith G, Wells N (eds). Medicines for the Year 2000. London: Office of Health Economics, 1979;1-11.

5. Grimshaw JM, Santesso N, Cumpston M, Mayhew A McGowan J. Knowledge for knowledge translation: the role of the Cochrane Collaboration. J Contin Educ Health Prof 2006;26:55-62.

6. Cochrane.org [Internet]. London: The Cochrane Collaboration [cited 2017 Apr 30]. Available from: http:// www.cochrane.org/about-us.
7. Cochrane.org [Internet]. London: The Cochrane Collaboration [cited 2017 Apr 30]. Available from: http:// www.cochrane.org/about-us/cochrane-groups.

8. Cochrane.org [Internet]. London: The Cochrane Collaboration [cited 2017 Apr 22]. Available from: http:// www.cochrane.org/contact/review-groups.

9. Puljak L, Rako D. Unapređenje medicinske prakse u Hrvatskoj pomoću Cochrane kolaboracije. Biochemica Medica 2009;19(3)260-5.

10. Cochrane.org [Internet]. London: The Cochrane Collaboration [cited 2017 Apr 30]. Available from http:// www.cochranelibrary.com/cochrane-database-of-systematic-reviews/index.html.

11. MacLehose $\mathrm{H}$, Hilton J. Changes to The Cochrane Library during The Cochrane Collaboration's first 20 years. Cochrane Database Syst Rev [Internet]. 2013;2. [cited 2017 Apr 30]. Available from: http://www.cochranelibrary.com/editorial/10.1002/14651858. ED000050.

12. Green S, Higgins JPT. Chapter 2: Preparing a Cochrane review. In: Higgins JPT, Green S (eds). Cochrane Handbook for Systematic Reviews of Interventions. London: The Cochrane Collaboration, 2011.

13. Light RJ, Pillemer DB. Summing Up: The Science of Reviewing Research. Cambridge (MA): Harvard University Press, 1984.

14. Higgins JPT, Deeks JJ. Chapter 7: Selecting studies and collecting data. In: Higgins JPT, Green S (eds). Cochrane Handbook for Systematic Reviews of Interventions. London: The Cochrane Collaboration, 2011.

15. Meade MO, Richardson WS. Selecting and appraisiing studies for a systematic review. Annals of Internal Medicine 1997;127:531-7.

16. Onlinecourses.science.psu.edu[Internet]. Pennsylvania: Pennsylvania State University [accessed 2017 Apr 23]. Available from: https://onlinecourses.science.psu.edu/ stat509/node/26.

17. Higgins JPT, Altman DG, Sterne JAC. Chapter 8: Assessing risk of bias in included studies. In: Higgins JPT, Green S (eds). Cochrane Handbook for Systematic Reviews of Interventions. London: The Cochrane Collaboration, 2011.

18. Bartolucci AA. Opis i tumačenje metodoloških i statističkih tehnika u metaanalizama. Biochemica Medica 2009; 19:127-36.

19. Higgins JPT, Altman DG, Sterne JAC. Chapter 9: Analysing data and undertaking metaanalyses. In: Higgins JPT, Green S (eds). Cochrane Handbook for Systematic Reviews of Interventions. London: The Cochrane Collaboration, 2011.

20. Poropat G, Giljaca V, Hauser G, Štimac D. Enteral nutrition formulations for acute pancreatitis. Cochrane Database Syst Rev [Internet]. 2015;3. [cited 2017 Apr 30]. Available from: http://onlinelibrary.wiley.com/ doi/10.1002/14651858.CD010605.pub2/full.

21. Higgins JPT, Green S, Scholten RJPM. Chapter 3: Maintaining reviews: updates, amendments and feedback. In: Higgins JPT, Green S (eds). Cochrane Handbook for Systematic Reviews of Interventions. London: The Cochrane Collaboration, 2011. 